\title{
DESRESPEITO AO DIREITO FINANCEIRO AFASTOU DILMA DO CARGO DE PRESIDENTE
}

Coluna publicada em 12.5.2016: <https://www.conjur.com.br/2016-mai-12/ mauricio-conti-desrespeito-direito-financeiro-afastou-dilma $>$

Os 55 Senadores que hoje votaram pelo recebimento da denúncia e afastaram do cargo a Presidente Dilma Rousseff no processo de impeachment escreveram uma página na história em que o Direito Financeiro ocupou papel de destaque, fato que não pode deixar de ser registrado.

Acusada de dois crimes de responsabilidade cujas condutas são diretamente relacionadas ao Direito Financeiro, seu afastamento do cargo não deixa mais dúvidas de que o orçamento é a lei mais importante do País depois da Constituição, ${ }^{1}$ e de que a Lei de Responsabilidade Fiscal não admite violações.

A Lei de Responsabilidade Fiscal - LRF, de 4 de maio de 2000, foi, ao longo desses dezesseis anos, ${ }^{2}$ se consolidando como norma fundamental para a administração pública, e a evolução em matéria de gestão fiscal foi pavimentando o caminho para que o País pudesse alcançar patamares mais elevados de respeitabilidade internacional e se colocasse no rumo para cumprir os objetivos fundamentais previstos na Constituição.

Essa trajetória foi ameaçada nos últimos anos com atos que a desrespeitavam, freando o avanço que vinha sendo experimentado, e importaram em inaceitável retrocesso que desviava desse curso.

Pude registrar ao longo dos últimos anos o desrespeito ao ordenamento jurídico em matéria de finanças públicas nas colunas publicadas na seção "Contas à Vista”, reunidas neste livro.

1 "A lei orçamentária é a lei materialmente mais importante do ordenamento jurídico logo abaixo da Constituição" (Min. Carlos Britto, p. 92 dos autos, STF, Tribunal Pleno, ADI 4.048 Rel. Min. Gilmar Mendes, j. 14.5.2008).

2 A informação refere-se à época da publicação original deste texto (maio de 2016). 
Práticas consagradas de uso de instrumentos orçamentários, como emendas parlamentares e transferências voluntárias, para viabilizar o "governo de coalizão", permaneceram tal e qual, mostrando que nada parecia evoluir na gestão das finanças públicas. ${ }^{3}$ Chegaram ao cúmulo de ser regulamentadas. ${ }^{4}$

As "maquiagens contábeis", registradas na coluna publicada em 12 de fevereiro de $2013,{ }^{5}$ foram o mais claro indício de que não se pretendia levar o Direito Financeiro a sério.

Atrasos na publicação da lei orçamentária anual, fazendo com que o ano se iniciasse com autorizações precárias para os gastos públicos, e terminasse postergando despesas para o ano seguinte, com aumentos cada vez mais significativos dos restos a pagar, voltavam a fazer crer que a lei orçamentária não passava de mera peça de ficção. ${ }^{6}$

O povo pode desconhecer as questóes técnicas que levam ao descontrole do governo, mas é o primeiro a sentir suas consequências; a insatisfação fica evidente e os protestos começam a aparecer. ${ }^{7}$

Ao planejamento, fundamental para qualquer governo que se pretenda eficiente e responsável, pouca atenção se dava. O Plano Nacional de Educação, cuja vigência expirou em 2010, só veio a ser renovado quatro anos depois. Um atraso que seria inaceitável em qualquer circunstância e se torna mais grave quando se sabe ser essa a "prioridade número um" para um País que tem como objetivos fundamentais reduzir as desigualdades sociais, erradicar a pobreza e se inserir no rol dos países desenvolvidos, além dos demais que a Constituição prevê em seu art. $3^{\circ}$ e para os quais a educação é o ponto de partida.

Com uma Presidente que se candidata à reeleição apresentando um pífio plano de governo, ${ }^{8}$ assume com o lema da "Pátria Educadora" e troca os ministros da pasta da Educação ao sabor das conveniências políticas do momento, fica a certeza de que o País se equipara a um transatlântico à deriva no oceano, sem saber o rumo

3 Colunas Emendas ao orçamento e o desequilíbrio de Poderes, publicada em 3 de julho de 2012, e Transferências voluntárias geram desequilíbrio federativo, publicada em 28 de agosto de 2012.

4 Decreto 8.389/2015, mencionado na coluna Direito financeiro precisa ser levado a sério, e 2015 começou mal, publicada em 10 de fevereiro de 2015.

5 Contas "maquiadas" não vão tornar nosso País mais bonito.

6 Colunas $E$ o ano começa sem a aprovação do orçamento federal, publicada em 15 de janeiro de 2013, e O final do ano, as dividas e os "restos a pagar", publicada em 17 de dezembro de 2013.

$7 \quad$ No fundo, protestos envolvem questôes orçamentárias, publicada em 2 de julho de 2013.

8 Planos de governo são essenciais para a escolha do próximo presidente, publicada em 21 de outubro de 2014. 
a seguir, quando era necessário enfrentar tempestades, e não apenas "marolinhas". O planejamento é deixado de lado, assume a "administração-bombeiro", e vive-se para apagar incêndios.

Aparecem as "pedaladas fiscais", ${ }^{10}$ com o uso dos bancos públicos para pagar contas do Tesouro sem lastro, associadas à falta de transparência nas operaçóes envolvendo o BNDES, ${ }^{11}$ e as maquiagens contábeis passam a ser uma prática recorrente, tornando a "contabilidade criativa" uma política de governo.

O dia 15 de abril transformou-se já há muitos anos numa data importante para o País, por ser a data de apresentação pelo Presidente da República da proposta de Lei de Diretrizes Orçamentárias - a LDO, ${ }^{12}$ sempre objeto de atenção da mídia. Mas as sucessivas alterações ocorridas nesta lei conseguiram fazer do dia 15 de abril o novo dia da mentira. O dia da mentira fiscal.

Um dos atos mais representativos do desrespeito ao ordenamento jurídico em matéria financeira, a desconsideração da LDO consegue ao mesmo tempo ferir vários princípios e valores caros ao governante: credibilidade, segurança jurídica e responsabilidade fiscal. Além de terem sido frequentemente aprovadas completamente fora do prazo legal, as leis de diretrizes orçamentárias, que têm a função de estabelecer as previsões de metas de resultado fiscal, responsáveis por conduzir a gestão orçamentária e financeira, viraram letra morta nos últimos anos, com as sucessivas alterações, chegando a despropósitos como o que ocorreu no ano passado, em que a meta foi substancialmente modificada poucos dias antes do término do exercício financeiro.

Atitudes como essa destroem a credibilidade do governante, fazendo com que esse dispositivo de lei deixe de merecer qualquer confiança. Torna-se inútil para conferir segurança jurídica, como se lei não fosse, e desconsidera sua função como parâmetro de responsabilidade fiscal. Um desastre para as finanças públicas e para quem a comanda.

Soma-se a isso o pouco caso que se fez da lei orçamentária, que parecem esquecer tratar-se da mais importante para o País depois da Constituição. Em 2015, é apresentado o projeto de lei orçamentária, sendo decidido no dia anterior, um domingo, que seria deficitário, como se o projeto da LDO, que havia fixado os

\footnotetext{
9 Descaso com o planejamento deixa o País sem rumo, publicada em 22 de setembro de 2015.

10 Atenção caro leitor, pedalar faz mal à saúde!, publicada em 23 de setembro de 2014.

11 BNDES tem o dever de colaborar com a transparência dos gastos públicos, publicada em 17 de novembro de 2015.

12 Ato das Disposições Transitórias da Constituição, art. 35, \ 2º, II.
} 
parâmetros, não existisse. Ante a repercussão negativa, e rebaixamento do País pelas agências de risco, promove-se alteração às pressas, jogando por terra qualquer credibilidade que os números apresentados pela lei orçamentária ainda pudessem vir a ter. ${ }^{13}$

Um conjunto de desmandos que não poderia resultar em outra coisa que não a decisão, pelo Tribunal de Contas da União, pela primeira vez após a Lei de Responsabilidade Fiscal, de dar parecer pela rejeição das contas de governo relativas ao exercício de 2014, quando muitas das ilegalidades apontadas já tinham sido praticadas. ${ }^{14}$

E, agora, com o recebimento da denúncia e afastamento da Presidente, a Nação passa a saber que infringir a lei orçamentária abrindo créditos sem autorização e "pedalar" não são meras irregularidades contábeis, mas crimes de responsabilidade que podem levar um Presidente a perder seu cargo. ${ }^{15}$

Causam prejuízos cujos montantes podem ultrapassar em muito os valores que se veem em matéria de desvio de recursos públicos. Prejuízos que não são somente financeiros, mas também e principalmente à imagem do País, que perde sua credibilidade perante o mundo todo, afastando investidores e desmotivando a sociedade, mostrando que a segurança jurídica é precária e não se tem qualquer apreço pela responsabilidade fiscal.

Razôes mais do que justas e suficientes para que o governante perca as condições de comandar a Nação.

O novo governo que se inicia hoje tem uma tarefa muito difícil. Recuperar a credibilidade, segurança jurídica e responsabilidade fiscal perdidas exigirá muito esforço, em curto espaço de tempo. Reverter, porém, as expectativas negativas que foram construídas em relação ao governo federal é missão árdua, mas não impossível.

O importante é que a principal lição foi aprendida: é preciso levar o Direito Financeiro a sério.

13 Descaso com o planejamento deixa o País sem rumo, publicada em 22 de setembro de 2015.

14 Julgamento do TCU que reprovou contas do governo entrou para a história do Direito Financeiro, publicada em 20 de outubro de 2015.

15 Agressôes ao Direito Financeiro dão razões para o impeachment, publicada em 5 de abril de 2016. 